to the national disadvantage to sterilize space by housing surplus stores or to scrap the stores, but also provide the departments, with the least possible delay, with the directions as to the strength and organization of the defence forces required after the War, which will enable them to determine which properties they will need to acquire and which of those now held they will eventually be able to release. Besides, the Select Committee recommends an independent review by the Government of the practice of departments in the retention of stores, and in this connexion the advice of Government scientific and research organizations should be sought in classifying stores according to their probable future use, having regard to scientific progress. The procedure for declaring stores obsolete also requires speeding up, and surplus stores and scrap arising overseas should, wherever possible, be disposed of without being brought back to Great Britain. Subject to political and strategic considerations, the fullest use should be made of storage facilities overseas for stores required for the war against Japan.

\section{Museums as Contemporary Educational Centres}

A memorandum received from Mrs. M. Harrison, acting curator of the Geffrye Museum, London, E.2, deals with the present-day problems of the creative use of leisure in an industrialized society - the education of children of a non-academic turn of mind, and the bridging of the gap that still tends to lie between school and the actualities of life. It is suggested that the solution lies in the establishment of centres specially equipped to show the individual, on a scale within his grasp, his place, meaning and purpose within the contemporary world. These centres could present in an appropriate manner a variety of visual material culled from industrial, commercial and public sources. They could also provide for courses of instruction in art and craft work and in contemporary social studies, educational film shows, facilities for study, and a scheme for loans to schools, with the view of encouraging further the individual's practical interest in, and investigation of, his or her surroundings in relation to the world at large.

Most of the plan is very feasible-indeed, several of the methods advocated have for some time been in successful operation in the 'village colleges' of Cambridgeshire; but it is difficult to accept the suggestion that it would be possible "to show the contemporary world ... the direction in which the whole world is moving", either for reasons of exhibition space, or of opinion. There is much within it, however, which might well claim the attention of 'centres' already in existence, such as the larger provincial museums. For example, some of these in presenting the geology of their various areas are already 'illustrating' the fundamentals (not mentioned in the plan) inseparable from some industries. Upon such foundations the institutions concerned might profitably build along the lines suggested, and thereby help to refute the accusation (recently made at a meeting of the British Association) that the majority of museums in Great Britain are out of touch with modern life.

\section{Burrell Art Collection for Glasgow}

THE Corporation of the City of Glasgow reports this important aequisition in its Art Gallery and Museums Report for the year 1943-44. Sir William Burrell's collection, which consists of pictures, tapestries, stained glass, furniture, carpets, porcelain, ivories, enamels and silver, has. long been associated with his name. It is probably most widely known for its tapestries, which include many of international importance. While presenting this valuable material for the cultural benefit of Glasgow, the donor has at the same time made provision for the purchase of additional works of art (more especially for those of the Gothic period), and for a special building to house it. This building will eventually be erected in the country not less than sixteen miles from the city.

\section{Cancer Control in Peru}

The August issue of the Boletin de la Oficina Sanitaria Panamericana contains an interesting article on this subject by Dr. Julio Bedoya Paredes, of the National Institute of Radiology of Peru, who states that since this Institute was founded two years ago a record has been kept of cases according to the site of the cancer, classification, treatment and results. The Institute includes a reception service, specialized clinics, such as gynæcology, surgery and internal medicine, X-ray, basal metabolism, laboratory and histopathology sections, statistical, health education and preventive sections. It is intended to create a biopsy service through which specimens may be sent by air to the Institute for diagnosis.

\section{Announcements}

DR. J. F. J. DipPING, head of the Chemistry Department at the Mining and Technical College, Wigan, has been appointed head of the Science Department at the South-East Essex Technical College, Dagenham.

To encourage the reading of papers by student members of the Institute of Fuel, also those taking courses at universities and technical colleges, the Council has decided to make an annual award of a medal together with a prize consisting of books and instruments to the value of $£ 5$. Particulars can be obtained from the Secretary, Institute of Fuel, 30 Bramham Gardens, London, S.W.5.

AT the anniversary meeting of the Royal Institution held on May 1, the following officers were elected : President, Lord Rayleigh; Treasurer, Sir Robert Robertson; Secretary, Dr. A. O. Rankine ; Managers, Prof. E. N. da C. Andrade, Dr. F. H. Carr, Sir Charles Darwin, Prof. Herbert Dingle, Dr. P. Dunsheath, Viscount Falmouth, Prof. G. I. Finch, Prof. C. L. Fortescue, Captain H. L. Hitchins, Mr. James Kewley, Mr. Arthur Marshall, Prof. H. R. Robinson, Dr. G. Shearer, Mr. H. S. Souttar, Sir George Thomson; Visitors, Brigadier R. A. 'Bagnold, Mr. J. G. Bennett, Mr. M. G. Bennett, Major W. H. Cadman, Dr. W. H. J. Childs, Mr. F. P. Dunn, Mr. Kenneth Gray, Dr. Wilfred Hall, Mr. James Henshilwood, Dr. W. Jevons, Mr. L. B. W. Jolley, Mr. G. S. W. Marlow, Prof. L. C. Martin, Mr. E. Kelly Maxwell, Prof. H. J. Plenderleith.

A course of six lectures on "The Problem of Freedom in a Planned Society" to be delivered on Wednesdays, beginning May 16, at 7.30 p.m., at Victory House Hall (N.S.P.C.C.), Leicester Square, Lond.on, W.C.2, has been arranged by the Progressive League. The speakers include Prof. H. Levy, Major Adrian Stephen, Prof. M. Polanyi, Prof. F. A. Hayek, Dr. C. A. Smith, and Prof. D. Mitrany. Tickets, $6 s$. for the course, $1 s$. $6 d$. for single lectures, can be obtained from the secretary of the Progressive League, 20 Buckingham Street, London, W.C.2, or at the door. 